\title{
KEPASTIAN HUKUM PENGGUNAAN MATA UANG RINGGIT OLEH MASYARAKAT DI DAERAH PERBATASAN INDONESIA-MALAYSIA
}

\section{LEGAL CERTAINTY OF THE USE OF RINGGIT CURRENCY BY PEOPLE IN THE BORDER REGION OF INDONESIA MALAYSIA}

\author{
Rivaldi Nugraha ${ }^{1}$ \\ Universitas Balikpapan \\ Jalan Pupuk Raya, Kelurahan Damai, Balikpapan, Kalimantan Timur \\ rivaldinugraha@uniba-bpn.ac.id
}

\begin{abstract}
ABSTRAK
Rumusan masalah dalam penelitian ini adalah bagaimanakah kepastian hukum terhadap penggunaan mata uang ringgit oleh masyarakat kabupaten nunukan di daerah perbatasan indonesia-malaysia serta apakah kendala yang dihadapi yang dihadapi dalam melakukan pengawasan sehingga tidak adanya keefektifan terhadap aturan hukum mengenai penggunaan mata uang ringgit oleh masyarakat di daerah perbatasan Indonesia-Malaysia.

Tujuan penelitian ini adalah untuk menguraikan segala permasalahan terkait dengan bentuk pengawasan dari pihak-pihak terkait yang didalamnya termasuk aparat penegak hukum, karena di dalam undang-undang Nomor 7 tahun 2011 tentang mata uang sudah mengatur jelas mengenai penggunaan mata uang rupiah, dan telah diatur bahwa mata uang Rupiah wajib digunakan di wilayah Negara Kesatuan Republik Indonesia (NKRI). Metode Penelitian ini penulis menggunakan pendekatan hukum yuridis normatif, yaitu penulis akan mengkonstruksikan rumusan normatif yang terdapat dalam peraturan perundang-undangan, norma-norma yang berkaitan dengan penggunaan mata uang ringgit di Daerah Perbatasan Indonesia-Malaysia.

Hasil dari penelitian, bahwa sangat diperlukannya kesadaran masyarakat terhadap regulasi yang telah ditetapkan oleh pemerintah Republik Indonesia dan regulasi tersebut harus dipaksakan penerapannya sehingga masyarakat wilayah perbatasan Indonesia-Malaysia tidak lagi menggunakan Mata Uang Ringgit.
\end{abstract}

Kata Kunci: Mata Uang; Ringgit; Perbatasan; Indonesia; Malaysia

\section{ABSTRACT}

The problem formulation in this research is how the legal certainty in the use of ringgit currency by the people of Nunukan district in the border area of Indonesia-Malaysia as well as whether the obstacles faced in conducting Supervision so that there is no effectiveness on 
the rule of law regarding the use of ringgit currency by the community in the border region of Indonesia-Malaysia.

The purpose of this research is to describe all issues related to the form of supervision of related parties including law enforcement officers, because in law number 7 year 2011 about the currency has been set clearly Regarding the use of Rupiah currency, and it has been stipulated that the rupiah currency must be used in the unitary State territory of the Republic of Indonesia (NKRI). The benefits of this research are expected from this research at least to the development of science, where this article is expected to be a new discourse material in redeepening the theoretical concepts of the law, including seeing Legal certainty on the use of ringgit currency in the border area of Indonesia-Malaysia. The research method of this author uses normative juridical legal approach, which is the author will construct the normative formulation contained in the legislation, norms relating to the use of ringgit currency in the region Indonesia-Malaysia border.

The result of the research show that public awareness of the regulations that have been set by the government of the Republic of Indonesia is more needed and implementation of regulations must be enforced, so that the peoples of the Indonesia-Malaysia border do not use the Ringgit currency.

Keywords: Currency, Ringgit, Border, Indonesia, Malaysia

\section{PENDAHULUAN}

\section{A. Latar Belakang}

Indonesia adalah Negara berkembang yang terletak di Benua Asia tepatnya Asia Tenggara, merupakan negara kepulauan yang terbesar di dunia dan berada di posisi geografis yang sangat strategis karena menjadi penghubung dua samudera dan dua benua, Samudera Hindia dengan Samudera Pasifik dan Benua Asia dan Benua Australia. Pulaupulau Indonesia berada diantara laut yang memisahkan antara pulau yang satu dengan pulau yang lainnya. ${ }^{1}$ Ada beberapa sumber yang menyatakan bahwa pulau yang dimiliki Indonesia berjumlah antara 17.504 pulau, 17.480 pulau, 17.508 pulau dan bahkan ada yang mengatakan lebih dari 17.000 pulau. $^{2}$

Negara Kesatuan Republik Indonesia sebagai negara yang merdeka dan berdaulat memiliki simbol kedaulatan negara yang harus dihormati dan dibanggakan oleh seluruh warga Negara Indonesia.Salah satu simbol kedaulatan negara tersebut adalah Mata Uang. Mata Uang yang dikeluarkan oleh Negara Kesatuan Negara Republik Indonesia adalah Mata Ung Rupiah. Mata Uang Rupiah dipergunakan sebagai alat pembayaran yang sah dalam kegiatan perekonomian nasional guna mewujudkan kesejahteraan sosial bagi seluruh rakyat Indonesia.

Berdasarkan Pasal 23 huruf B Undang-Undang Dasar Negara Republik Indonesia Tahun 1945 yang berbunyi bahwa "macam dan harga Mata Uang ditetapkan dengan undang-undang". Penetapan dan pengaturan tersebut diperlukan untuk memberikan pelindungan dan kepastian hukum bagi Mata Uang yang berlaku.Rupiah sebagai Mata uang Negara Kesatuan Republik Indonesia sesungguhnya telah diterima dan digunakan sejak kemerdekaan. Dalam sejarah pengaturan macam dan harga mata uang di Indonesia

\footnotetext{
${ }^{1}$ http://www.dkn.go.id/site/index.php/ruang-opini/126-jumlah-pulau-di-Indonesia, diakses tanggal 21 April 2016, jam 15:43 WITA

${ }^{2}$ https://databoks.katadata.co.id/datapublish/2018/10/16/berapa-jumlah-pulau-di-indonesia, diakses tanggal 7 Juli 2019, jam 1:58 WITA
} 
setelah masa kemerdekaan, pernah dibentuk 4 (empat) undang-undang yang mengatur Mata Uang yaitu:

a. Undang-Undang Darurat Nomor 20 Tahun 1951 Tentang Penghentian Berlakunya "Indische Mutwet 1912" dan Penetapan Peraturan BaruTentang Mata Uang.

b. Undang-Undang Darurat Nomor 20 Tahun 1951 Tentang Penghentian Berlakunya "Indische Mutwet 1912" dan Penetapan Peraturan BaruTentang Mata Uang.

c. Undang-Undang Darurat Nomor 4 Tahun 1985 Tentang Pengubahan "UndangUndang Mata Uang Tahun 1953".

d. Undang-Undang Nomor 71 Tahun 1985 tentang Pengubahan "Undang-Undang Mata Uang Tahun 1953" sebagai Undang-Undang.

Penerbitan keempat undang-undang di atas bukan sebagai pelaksanaan amanat Undang-Undang Dasar Negara Republik Indonesia 1945, melainkan sebagai pelaksanaan amanat Pasal 109 ayat (4) Undang-Undang Dasar Sementara Tahun 1950.

Kehidupan perekonomian suatu negara, peranan uang sangatlah penting karena uang mempunyai beberapa fungsi, antara lain sebagai alat penukar atau alat pembayar dan pengukur harga sehingga dapat dikatakan bahwa uang merupakan salah satu alat utama perekonomian. Dengan uang, perekonomian suatu negara akan berjalan dengan baik sehingga mendukung tercapainya tujuan bernegara, yaitu mencapai masyarakat adil dan makmur. Selain itu, jika dilihat secara khusus dari bidang moneter, jumlah uang yang beredar dalam suatu negara harus dikelola dengan baik sesuai dengan kebutuhan perekonomian. Karena melihat perannya yang sangat penting, uang harus dibuat sedemikian rupa agar sulit ditiru atau dipalsukan oleh pihak yang tidak bertanggung jawab. Disinilah peran otoritas yang profesional sangat diperlukan untuk menentukan ciri, desain, dan bahan baku Rupiah.

Rupiah merupakan mata uang dan sebagai alat tukar resmi negara Indonesia yang digunakan dalam kesehariannya, sedangkan jenisnya terbagi atas uang kertas dan uang logam. Berdasarkan Pasal 1 Undang-Undang Nomor 7 Tahun 2011 Tentang Mata Uang, telah dijelaskan mengenai pengertian uang kertas dan uang logam, bahwa uang kertas adalah bahan baku yang digunakan untuk membuat rupiah kertas yang mengandung unsur pengaman dan yang tahan lama, sedangkan uang logam sendiri merupakan bahan baku yang digunakan untuk membuat rupiah logam yang mengandung unsur pengaman dan yang tahan lama.

Undang-Undang Nomor 7 Tahun 2011 Tentang mata uang mewajibkan penggunaan Rupiah dalam setiap transaksi yang mempunyai tujuan pembayaran, penyelesaian kewajiban lainnya yang harus dipenuhi dengan uang, dan/atau transaksi keuangan lainnya, yang dilakukan di Wilayah Negara Kesatuan Republik Indonesia. Kepercayaan masyarakat Indonesia terhadap Rupiah akan berdampak pada kepercayaan masyarakat internasional terhadap Rupiah dan perekonomian nasional pada umumnya sehingga rupiah memiliki martabat, baik di dalam negeri maupun di luar negeri dan Rupiah terjaga kestabilannya.

Undang-Undang tentang mata uang menekankan pula pada Pengelolaan Rupiah yang terintegrasi, mulai dari perencanaan jumlah rupiah yang akan dicetak, Pencetakan Rupiah, 
Pengeluaran rupiah, Pengedaran rupiah, serta Penarikan dan Pencabutan rupiah sampai dengan Pemusnahan rupiah dengan tingkat pengawasan yang komprehensif sehingga ada check and balances antar pihak yang terkait agar tercipta good governance. Penegakan hukum terkait kejahatan Mata Uang, terutama pemalsuan rupiah, memerlukan pengaturan yang memberikan efek jera bagi pelaku karena efek kejahatan tersebut berdampak luar biasa terhadap perekonomian dan martabat bangsa secara keseluruhan, oleh karena itu, setiap orang yang melanggar ketentuan dalam Undang-Undang tentang mata uang akan dikenai sanksi pidana yang sangat berat.

Kabupaten Nunukan Kalimantan Utara merupakan wilayah kesatuan republic indonesia, yang berbatasan langsung dengan Negara Malaysia, mata uang yang berlaku tidak semata-mata hanya rupiah saja, melainkan mata uang ringgit yang digunakan dalam bertransaksi dikehidupan sehari-hari, seperti membeli kebutuhan pokok sandang dan pangan untuk kehidupan mereka, hal ini menjadi problematika yang sangat serius, karena dalam Pasal 21 ayat (1) Undang-Undang Nomor 7 Tahun 2011 Tentang Mata Uang, yang berbunyi:

"Rupiah wajib digunakan dalam:

a. setiap transaksi yang mempunyai tujuan pembayaran;

b.penyelesaian kewajiban lainnya yang harus dipenuhi dengan uang; dan/atau;

c.transaksi keuangan lainnya yang dilakukan di Wilayah Negara Kesatuan Republik Indonesia."

Pasal di atas menunjukkan bahwa rupiah merupakan mata uang yang wajib digunakan di Negara Kesatuan Republik Indonesia dalam bertransaksi. Pasal 33 Ayat (1) UndangUndang Nomor 7 Tahun 2011 Tentang Mata Uang juga menegaskan bahwa:

"Setiap orang yang tidak menggunakan Rupiah dalam:

a. setiap transaksi yang mempunyai tujuan pembayaran;

b.penyelesaian kewajiban lainnya yang harus dipenuhi dengan uang; dan/atau

c.transaksi keuangan lainnya sebagaimana dimaksud dalam Pasal 21 ayat (1) dipidana dengan pidana kurungan paling lama 1 (satu) tahun dan pidana denda paling banyak Rp.200.000.000,00 (dua ratus juta rupiah)."

Berbagai cara telah dilakukan oleh pemerintah, dengan mensosialisasikan UndangUndang Nomor 7 Tahun 2011 Tentang Mata Uang, bahkan Bank Indonesia (BI) juga memperbanyak dan menyebarluaskan uang kertas serta uang logam di wilayah Kabupaten Nunukan Kalimantan Utara tersebut, tetapi belum juga dapat mengatasi permasalahan di wilayah perbatasan Indonesia-Malaysia itu, hingga pada tahun 2016 peneliti melakukan peninjauan langsung ke lapangan untuk melakukan penelitian guna memenuhi salah satu syarat untuk menempuh siding akhir (skripsi), dan pada saat melakukan penelitian sampai pada saat selesainya melakukan penelitian, peneliti mendapatkan kesimpulan bahwa di Kabupaten Nunukan Provinsi Kalimantan Utara berdasarkan keterangan dari Kasat Reskrim Polres Nunukan dan salah satu masyarakat, masih sulit untuk diterapkan sesuai dengan yang tercantum di Undang-Undang Nomor 7 Tahun 2011 tentang Mata Uang dikarenakan ada beberapa hal penting terlebih dahulu yang menjadi PR untuk pemerintah Indonesia, bahkan problema yang terjadi di perbatasan tersebut sudah menjadi kebiasaan ataupun membudaya. 


\section{B. Rumusan Masalah}

Berdasarkan uraian latar belakang masalah yang di atas kaitannya dengan Penggunaan Mata Uang Ringgit Di Daerah Perbatasan Indonesia-Malaysia Ditinjau Dari sisi Kepastian Hukum dan Kedaulatan Negara, maka penulis menarik beberapa pertanyaan penelitian yang dirumuskan sebagai berikut: Bagaimanakah Kepastian Hukum terhadap Penggunaan Mata Uang Ringgit Oleh Masyarakat Kabupaten Nunukan di Daerah Perbatasan Indonesia-Malaysia?

\section{Metode}

Penelitian ini penulis menggunakan pendekatan hukum yuridis normatif, yaitu penulis akan mengkonstruksikan rumusan normatif yang terdapat dalam peraturan perundangundangan, norma-norma yang berkaitan dengan penggunaan mata uang ringgit di Daerah Perbatasan Indonesia-Malaysia. Penelitian ini mengkaji hukum berdasarkan konsep kepastian hukum dan konsep kedaulatan negara dalam menerapkan Undang-undang Nomor 7 Tahun 2011 tentang mata uang di daerah perbatasan Indonesia Malaysia.

\section{Tinjauan Pustaka}

\section{Pengertian Uang}

Pengertian Uang adalah sesuatu yang dapat diterima secara umum sebagai alat pembayaran dalam suatu wilayah tertentu atau sebagai alat pembayaran utang atau sebagai alat untuk melakukan pembelian barang dan jasa. Dengan kata lain, bahwa uang merupakan alat yang dapat digunakan dalam melakukan pertukaran baik barang maupun jasa dalam suatu wilayah tertentu saja. Kemudian uang biasanya hanya dapat dipergunakan dalam satu wilayah tertentu, misalnya negara, karena bisa saja satu mata uang tertentu tidak berlaku di negara lain dan sebaliknya, namun bisa saja satu mata uang negara tertentu berlaku di semua negara seperti mata uang US Dollar.

Kriteria sesuatu agar dapat dikatakan sebagai uang haruslah memenuhi persyaratan sebagai berikut. ${ }^{3}$

1) Ada Jaminan

Setiap uang yang diterbitkan dijamin oleh pemerintah negara tertentu.Dengan adanya jaminan dari pemerintah tertentu, maka kepercayaan untuk menggunakan uang untuk berbagai keperluan mendapat kepercayaan dari masyarakat luas.

2) Disukai Umum

Artinya uang harus dapat diterima secara umum penggunaannya apakah sebagai alat tukar, penimbun kekayaan atau sebagai standar pencicilan utang.

3) Nilai Yang Stabil

Nilai uang harus memiliki kestabilan dan ketetapan serta diusahakan fluktuasinya sekecil mungkin. Apabila nilai uang sering mengalami ketidakstabilan, maka akan sulit untuk dipercaya oleh yang menggunakannya.

${ }^{3}$ Ibid, hlm.15 
4) Mudah Disimpan

Uang harus mudah disimpan di berbagai tempat termasuk dalam tempat yang kecil, namun dalam jumlah yang besar.

5) Mudah Dibawa

Uang harus mudah dibawa ke mana pun dengan kata lain mudah untuk dipindahkan dari satu tempat ke tempat lain atau dari satu tangan ke tangan yang lain dengan fisik kecil dan nominal besar sekalipun.

6) Tidak Mudah Rusak

Uang hendaknya tidak mudah rusak dalam berbagai kondisi, baik robek atau luntur terutama kondisi fisiknya mengingat frekuensi pemindahan uang dari satu tangan ke tangan lainnya demikian besar.Dalam hal ini yang perlu diperhatikan adalah kualitasnya sehingga uang dapat digunakan untuk waktu yang relative lama.

7) Mudah Dibagi

Uang mudah dibagi ke dalam satuan unit tertentu dengan berbagai nominal yang ada guna kelancaran dalam melakukan transaksi, mulai dari nominal kecil sampai dengan nominal yang besar sekalipun.

8) Suplai harus elastis

Agar perdagangan dan usaha menjadi lancar jumlah uang yang beredar di masyarakat haruslah mencukupi.Tersedianya uang dalam jumlah yang cukup disesuaikan dengan kondisi usaha atau kondisi perekonomian suatu wilayah.

Fungsi- fungsi dari uang secara umum yang ada dewasa ini adalah sebagai berikut. ${ }^{4}$

1) Alat Tukar-menukar

2) Satuan Hitung

3) Penimbun Kekayaan

4) Standar Pencicilan Utang

Peredaran menurut KBBI berarti gerakan (perjalanan dan sebagainya) berkeliling (berputar), keadaan beredar, peralihan (pergantian) dari keadaan yang satu ke keadaan yang lain yang berulang-ulang seakan-akan merupakan suatu lingkaran, dan perputaran (uang) dalam masyarakat, serta di Pasal 1 angka 14 Undang-Undang Nomor 7 Tahun 2011 Tentang Mata Uang sendiri telah menjelaskan mengenai pengertian pengedaran, yaitu: "Pengedaran adalah suatu rangkaian kegiatan mengedarkan atau mendistribusikan Rupiah di Wilayah Negara Kesatuan Republik Indonesia”.

Adapun faktor-faktor yang mempengarui beredarnya uang, yaitu: ${ }^{5}$

1) Faktor-faktor yang mempengarui multipier uang: yaitu faktor-faktor determinan uang itu sendiri anatara lain: biaya penggunaan uang giral, kenyamanan dan keamanan, biaya relatif yaitu suku bunga, pendapatan masyarakat, kemajuan layanan sektor perbankan, ketentuan otoritas moneter dan keperluan bank akan likuiditas jangka pendek.

2) Faktor-faktor yang mempengarui perubahan uang primer: terkait dengan perubahan transaksi keuangan masyarakat yang tercermin pada neraca otoritas moneter, baik dari sisi uang primer (pasiva) maupun pada yang mempengarui uang primer (aktiva).

${ }^{4}$ Ibid, hlm. 17

${ }^{5}$ Solikin, 2002, Uang: Pengertian, Penciptaan, dan Peranannya dalam Perekonomian, Jakarta: PPSK BI hlm 39 


\section{Pengertian Kepastian Hukum}

Kepastian adalah perihal (keadaan) yang pasti, ketentuan atau ketetapan. Hukum secara hakiki harus pasti dan adil. Pasti sebagai pedoman kelakukan dan adil karena pedoman kelakuan itu harus menunjang suatu tatanan yang dinilai wajar. Hanya karena bersifat adil dan dilaksanakan dengan pasti hukum dapat menjalankan fungsinya. Kepastian hukum merupakan pertanyaan yang hanya bisa dijawab secara normatif, bukan sosiologi. ${ }^{6}$

Menurut Utrecht, kepastian hukum mengandung dua pengertian, yaitu pertama, adanya aturan yang bersifat umum membuat individu mengetahui perbuatan apa yang boleh atau tidak boleh dilakukan, dan kedua, berupa keamanan hukum bagi individu dari kesewenangan pemerintah karena dengan adanya aturan yang bersifat umum itu individu dapat mengetahui apa saja yang boleh dibebankan atau dilakukan oleh Negara terhadap individu. $^{7}$

Menurut Gustav Radbruch keadilan dan kepastian hukum merupakan bagian-bagian yang tetap dari hukum. Beliau berpendapat bahwa keadilan dan kepastian hukum harus diperhatikan, kepastian hukum harus dijaga demi keamanan dan ketertiban suatu negara. Akhirnya hukum positif harus selalu ditaati. Berdasarkan teori kepastian hukum dan nilai yang ingin dicapai yaitu nilai keadilan dan kebahagiaan. ${ }^{8}$

Jika dikaitkan teori kepastian hukum dalam suatu aturan perihal dengan Pasal 21 Ayat (1) dan Pasal 33 Ayat (1) Undang-Undang Nomor 7 Tahun 2011 Tentang Mata Uang. Kepastian memberikan kejelasan dalam suatu praktek yang seharusnya diberlakukan dalam suatu masyarakat, yang mana aturan atau Pasal tersebut belum sama sekali diberlakukan di Wilayah perbatasan Indonesia-Malaysia khususnya di daerah Nunukan Kalimantan Utara.

\section{PEMBAHASAN}

Kepastian Hukum terhadap Penggunaan Mata Uang Ringgit Oleh Masyarakat Kabupaten Nunukan di Daerah Perbatasan Indonesia-Malaysia

Menurut Gustav Radbruch, hukum harus mengandung 3 (tiga) nilai identitas, yaitu sebagai berikut,

A. Asas kepastian hukum (rechmatigheid), Asas ini meninjau dari sudut yuridis.

B. Asas keadilan hukum (gerectigheit), Asas ini meninjau dari sudut filosofis, dimana keadilan adalah kesamaan hak untuk semua orang di depan pengadilan.

C. Asas kemanfaatan hukum (zwechmatigheid) atau doelmatigheid atau utility.

\footnotetext{
${ }^{6}$ Dominikus Rato, Filsafat Hukum Mencari: Memahami dan Memahami Hukum, Laksbang Pressindo, Yogyakarta, 2010, hlm.59

${ }^{7}$ Riduan Syahrani, Rangkuman Intisari Ilmu Hukum, Penerbit Citra Aditya Bakti,Bandung, 1999, hlm.23.

${ }^{8}$ Ibid, hlm 95
} 
Tujuan hukum yang mendekati realistis adalah kepastian hukum dan kemanfaatan hukum. Kaum Positivisme lebih menekankan pada kepastian hukum, sedangkan Kaum Fungsionalis mengutamakan kemanfaatan hukum, dan sekiranya dapat dikemukakan bahwa "summon ius, summa injuria, summa lex, summa crux" yang artinya adalah hukum yang keras dapat melukai, kecuali keadilan yang dapat menolongnya, dengan demikian kendatipun keadilan bukan merupakan tujuan hukum satu-satunya akan tetapi tujuan hukum yang substantive adalah keadilan. ${ }^{9}$

Menurut Utrecht, kepastian hukum mengandung dua pengertian, yaitu pertama adanya aturan yang bersifat umum membuat individu mengetahui perbuatan apa yang boleh atau tidak boleh dilakukan, dan kedua, berupa keamanan hukum bagi individu dari kesewenangan pemerintah karena dengan adanya aturan yang bersifat umum itu individu dapat mengetahu apa saja yang boleh dibebankan atau dilakukan oleh Negara terhadap individu. Kepastian hukum ini berasal dari ajaran YuridisDogmatik yang didasarkan pada aliran pemikiran Positivisme di dunia hukum yang cenderung melihat hukum sebagai sesuatu yang otonom yang mandiri, karena bagi penganut aliran ini, tujuan hukum tidak lain sekedar menjamin terwujudnya oleh hukum yang bersifat umum. Sifat umum dari aturan-aturan hukum membuktikan bahwa hukum tidak bertujuan untuk mewujudkan keadilan atau kemanfaatan, melainkan semata-mata untuk kepastian. ${ }^{10}$

Dasar analisis penulis menggunakan salah satu teori kepastian hukum yang dipopulerkan oleh satu pakar.

Pendapat mengenai kepastian hukum dikemukakan oleh Jan M. Otto, yaitu bahwa kepastian hukum dalam situasi tertentu mensyaratkan sebagai berikut: ${ }^{11}$

1. Tersedia aturan-aturan hukum yang jelas atau jernih, konsisten dan mudah diperoleh (accesible), yang diterbitkan oleh kekuasaan negara;

2. Bahwa instansi-instansi penguasa (pemerintahan) menerapkan aturan-aturan hukum tersebut secara konsisten dan juga tunduk dan taat kepadanya;

3. Bahwa mayoritas warga pada prinsipnya menyetujui muatan isi dan karena itu menyesuaikan perilaku mereka terhadap aturan-aturan tersebut;

4. Bahwa hakim-hakim (peradilan) yang mandiri dan tidak berpihak menerapkan aturanaturan hukum tersebut secara konsisten sewaktu mereka menyelesaikan sengketa hukum; dan

5. Bahwa keputusan peradilan secara konkrit dilaksanakan.

Kelima syarat yang dikemukakan Jan M. Otto tersebut menunjukkan bahwa kepastian hukum dapat dicapai jika substansi hukumnya sesuai dengan kebutuhan masyarakat. Aturan hukum yang mampu menciptakan kepastian hukum adalah hukum yang lahir dari dan mencerminkan budaya masyarakat. Kepastian hukum yang seperti inilah yang disebut dengan kepastian hukum yang sebenarnya (realistic legal certainly), yaitu mensyaratkan

\footnotetext{
${ }^{9}$ Dosminikus Rato, Filasafat Hukum Mencari dan Memahami Hukum, PT Presindo, Yogyakarta, 2010, hlm. 59.

${ }^{10}$ Riduan Syahrani, Rangkuman Intisari Ilmu Hukum, Citra Aditya, Bandung, 1999, hlm. 23.

${ }^{11}$ Shidarta, B. Arief, Hukum dan Logika, Bandung;alumni, 2006, hlm 85
} 
adanya keharmonisan antara negara dengan rakyat dalam berorientasi dan memahami sistem hukum.

Apabila dikaitkan dengan pembahasan di bab 2 ini dan diuraikan satu demi satu untuk memperjelas suatu hubungan antara teori dengan apa yang telah menjadi permasalahan di Kabupaten Nunukan tersebut, penulis mengambil 3 poin penting pada Teori Kepastian Hukum oleh Jan. M. Otto tersebut, yaitu;

1. Tersedia aturan-aturan hukum yang jelas atau jernih, konsisten dan mudah diperoleh (accesible), yang diterbitkan oleh kekuasaan negara.

Pemerintah Republik Indonesia telah membuat regulasi yang jelas dan mudah dipahami oleh masyarakat, contohnya saja telah terbentuknya Undang-Undang Nomor 7 Tahun 2011 tentang Mata Uang, dalam hal ini Undang-Undang tersebut telah menerangkan secara jelas dan mudah dipahami khususnya di dalam Pasal 21 Ayat (1), berbunyi;

1) Rupiah wajib digunakan dalam:

a. setiap transaksi yang mempunyai tujuan pembayaran;

b. penyelesaian kewajiban lainnya yang harus dipenuhi dengan uang; dan/atau;

c. transaksi keuangan lainnya yang dilakukan di Wilayah Negara Kesatuan Republik Indonesia."

dan Pasal 33 Ayat (1), berbunyi;

1) Setiap orang yang tidak menggunakan Rupiah dalam:

a. setiap transaksi yang mempunyai tujuan pembayaran;

b. penyelesaian kewajiban lainnya yang harus dipenuhi dengan uang; dan/atau

c. transaksi keuangan lainnya sebagaimana dimaksud dalam Pasal 21 ayat (1) dipidana dengan pidana kurungan paling lama 1 (satu) tahun dan pidana denda paling banyak Rp200.000.000,00 (dua ratus juta rupiah).

Dua Pasal di atas merupakan potongan dari Undang-Undang Nomor 7 Tahun 2011 tentang Mata Uang yang mana merupakan suatu Regulasi yang menjadi dasar penulis untuk melakukan penelitian lebih lanjut dan membuktikan pula sebenarnya aturan itu telah ada, akan tetapi sangat amat sulit untuk diterapakan di Masyarakat Kabupaten Nunukan Kalimantan Utara yang merupakan daerah perbatasan Indonesia dengan Malaysia.

2. Bahwa instansi-instansi penguasa (pemerintahan) menerapkan aturan-aturan hukum tersebut secara konsisten dan juga tunduk dan taat kepadanya;

Pada poin kedua ini bahwa pemerintahan menerapkan aturan-aturan hukum secara konsisten dan juga tunduk dan taat pada aturan tersebut, pada fakta dilapangannya di daerah Kabupaten Nunukan Kalimantan Utara tersebut pemerintah sebenarnya tunduk pada aturan yang telah ada akan tetapi apabila menjurus pada Masyarakat yang berada di daerah tersebut khususnya pedagang, tidak dapat lagi menolak apabila ada warga yang melakukan transaksi menggunakan mata uang ringgit, dikarenakan sudah merupakan kebiasaan dan pedagang merasa mendapat keuntungan apabila mendapatkan ringgit. 
Berdasarkan hasil penelitian penulis pada Skripsi di tahun 2016, pada saat melakukan Wawancara dengan salah satu pedagang bernama Mujahiddin di Kabupaten Nunukan Kalimantan Utara, alasan mengapa masyarakat khususnya pedagang menerima dan merasa untung apabila menerima transaksi mata uang ringgit guna di Investasikan dan ditukarkan apabila uang rupiah naik dan untuk menukarkan pula masyarakat tidak mengalami kesulitan, dikarenakan banyak Kegiatan Usaha Penukaran Valuta Asing (KUPVA) yang tidak terhitung jumlahnya.

3. Bahwa mayoritas warga pada prinsipnya menyetujui muatan isi dan karena itu menyesuaikan perilaku mereka terhadap aturan-aturan tersebut;

Setiap warga negara pasti mengikuti hal-hal apa saja yang terbentuk dari pemerintahan yang menguntungkan daeranya, jika mengarah pada penelitian penulis yang saat ini, penggunaan mata uang ringgit di Wilayah Kesatuan Republik Indonesia (NKRI) jangan dianggap sebagai permasalahan sepele, masyarakat di Perbatasan Indonesia-Malaysia khususnya Kabupaten Nunukan Kalimantan Utara pada mungkin setuju adanya regulasi yang mengatur hal tersebut, tetapi apa daya regulasi tersebut pun belum efektif untuk mengatur permasalahan yang terjadi di daerah perbatasan Indonesia-Malaysia itu.

Membahas mengenai mayoritas warga atau masyarakat harus menyetujui muatan isi dan regulasi itu menyesuaikan perilaku masyarakat, penulis yakin hanya sebagian kecil warga yang setuju dan regulasi tersebut tetap di terbitkan, dapat terlihat dari kehidupan masyarakat di Kabupaten Nunukan Kalimantan Utara dan berdasarkan wawancara dari salah satu warga dan Kasat Reskrim Kepolisian Republik Indonesia di Nunukan AKP. Suparno, S.Sos, kebiasaan menggunakan Uang Ringgit di daerah tersebut sudah merupakan kebiasaan umum dan mendarah daging dan Posisi atau keberadaan yang berbatasan langsung dengan Malaysia yang memungkinkan masyarakat menggunakan mata uang ringgit serta Masyarakat di Malaysia sulit di bedakan dari segi keturunan, status identitas legal Malaysia namun dari segi keturunan mereka Indonesia yang sudah lama disana dan dari segi kekerabatan serta kekeluargaan mereka tidak bisa dipisahkan karena masih ada hubungan keluarga dan hanya negara yang membatasi.

4. Bahwa hakim-hakim (peradilan) yang mandiri dan tidak berpihak menerapkan aturan-aturan hukum tersebut secara konsisten sewaktu mereka menyelesaikan sengketa hukum; dan

Hakim merupakan Wakil Tuhan di Bumi, setiap putusan yang dibacakan hakim selalu menjadi putusan yang bersifat mengikat dan tidak dapat diganggu gugat, terkait dengan permasalahan hukum yang terjadi didaerah Perbatsan Indonesia-Malaysia, Penggunaan Mata Uang Ringgit merupakan permasalahan serius yang dipandang sebelah mata, sehingga berangsur-angsur tidak ada solusi, sehingga apabila dikaitkan dengan pendapat Jan. M. Otto mengenai teori Kepastian Hukum, bahwasannya selama ini permasalahan yang penulis teliti belum pernah masuk di ranah pengadilan, sehingga Hakim belum pernah membuat putusan yang mengikat dengan permasalahan hukum ini, tetapi penulis berspekulasi akan timbul masalah baru dan akan menjadi bahan diskusi para pakar hukum apabila permasalahan hukum yang terjadi di daerah perbatasan Indonesia-Malaysia masuk ke ranah pengadilan, mengapa penulis dapat 
berspekulasi demikian, dikarenakan permasalahan tersebut bukan semata-mata dilakukan oleh satu orang, tetapi banyak orang yang dikategorikan sebagai Masyarakat, khususnya Masyarakat Kabupaten Nunukan Kalimantan Utara.

\section{Bahwa keputusan peradilan secara konkrit dilaksanakan.}

Sampai pada poin terakhir pendapat Jan. M. Otto mengenai teori Kepastian Hukum, di poin lima ini bahwa putusan peradilan secara konkrit dilaksanakan, sama dengan penjelasan di poin empat sebelumnya, penulis berspekulasi akan timbul masalah baru yang akan menjadi bahan diskusi oleh para pakar hukum di Indonesia, akan tetapi poin lima ini merupakan poin penting pula, apabila suatu saat nanti permasalahan hukum yang terjadi di daerah perbatasan Indonesia-Malaysia khususnya di Kabupaten Nunukan Kalimantan Utara masuk diranah pengadilan dan bahkan teruntuk daerah perbatasan Indonesia dengan Negara lainnya, bukan hanya perbatasan dengan Malaysia.

Berdasarkan kelima poin di atas dikaitkan dengan pendapat Jan. M. Otto mengenai kepastian hukum bahwa memberlakukan ataupun membuat regulasi yang wajib untuk diikuti oleh masyarakat bahkan mengikuti perilaku masyarakat untuk terbentuknya suatu regulasi itu sangat sulit, dikarenakan di Kabupaten Nunukan Kalimantan Utara diyakini hanya sebagian kecil warga atau masyarakat yang setuju untuk dibuat suatu aturan untuk tidak menggunakan mata uang ringgit di Wilayah Negara Kesatuan Republik Indonesia (NKRI), tetapi regulasi itu tetap dibuat dan ketidak efektifan dalam penegakan Pasal 21 dan 33 Undang-Undang Nomor 7 Tahun 2011 tentang Mata Uang tersebut terjadi dari Undang-Undang tersebut di sahkan sampai dengan sekarang ini, regulasi tersebut hanya menjadi hiasan dan terabaikan, serta banyak pula tindakan pemerintah untuk mengatasi permasalahan tersebut dari penyebaran Mata Uang Kartal yang diperbanyak dan sosialisasi Undang-Undang yang tidak mendapatkan hasil memuaskan.

\section{PENUTUP}

Penggunaan mata uang ringgit oleh masyarakat di daerah Perbatasan IndonesiaMalaysia merupakan permasalahan hukum yang serius, dikarenakan apa yang dilakukan masyarakat perbatasan tersebut sangat amat dilarang dan diwajibkan menggunakan Mata Uang Rupiah sesuai dengan yang tercantum pada Pasal 21 dan 33 Undang-Undang Nomor 7 Tahun 2011 tentang Mata Uang.

Penelitian ini merupakan penelitian lanjutan, dimana penulis saat menempuh strata 1 (satu) penelitian ini sudah dilakukan dan mendapatkan hasil bahwa belum ada solusi yang efektif hingga sampai saat ini hanya solusi-solusi terdahulu yang masih diberlakukan, sehingga pada penelitian lanjutan ini penulis menggunakan Teori Kepastian Hukum yang dipopulerkan oleh Jan. M. Otto dan Teori Kedaulatan Negara yang dipopulerkan oleh George Jellinek dan dilanjutkan oleh Jean Bodin guna dapat memecahkan permasalahan hukum yang terjadi di daerah perbatasan Indonesia-Malaysia tersebut khususnya Kabupaten Nunukan Kalimantan Utara. Bahwa perlu adanya kepastian hukum dalam hal penggunaan mata uang bagi penduduk suatu negara, hal ini dapat diupayakan melalui: keterersedia aturan-aturan hukum yang jelas atau jernih, 
ISSN (Print): 2085-8477; ISSN (Online): 2655-4348

konsisten dan mudah diperoleh (accesible), yang diterbitkan oleh kekuasaan negara; bahwa instansi-instansi penguasa (pemerintahan) menerapkan aturan-aturan hukum tersebut secara konsisten dan juga tunduk dan taat kepadanya; bahwa mayoritas warga pada prinsipnya menyetujui muatan isi dan karena itu menyesuaikan perilaku mereka terhadap aturan-aturan tersebut; bahwa hakim-hakim (peradilan) yang mandiri dan tidak berpihak menerapkan aturan-aturan hukum tersebut secara konsisten sewaktu mereka menyelesaikan sengketa hukum; dan bahwa keputusan peradilan secara konkrit dilaksanakan. Lima poin tersebut seharusnya diterapkan pada kondisi di daerah perbatasan Indonesia-Malaysia khususnya Kabupaten Nunukan Kalimantan Utara, tetapi pada faktanya poin satu sampai dengan poin tiga pun penulis rasa belum secara penuh terlaksana. Jika melihat apa yang terjadi di daerah perbatasan Indonesia-Malaysia, permasalahan tersebut sudah melanggar kedaulatan Negara Kesatuan Republik Indonesia, dimana Mata Uang merupakan identitas Negara Indonesia yang seharusnya dijunjung tinggi akan tetapi masyarakat perbatasan tersebut malah menggunakan identitas negara tetangga.

\section{DAFTAR PUSTAKA}

Dominikus Rato, Filsafat Hukum Mencari: Memahami dan Memahami Hukum, Laksbang Pressindo, Yogyakarta, 2010

Peter Mahmud Marzuki, Pengantar Ilmu Hukum, Kencana, Jakarta, 2008

Cst Kansil, Christine, S.T Kansil, Engelien R, Palandeng dan Godlieb N Mamahit, Kamus Istilah Hukum, Jakarta, 2009

Riduan Syahrani, Rangkuman Intisari Ilmu Hukum, Penerbit Citra Aditya Bakti,Bandung, 1999

Achmad Ali, Menguak Tabir Hukum (Suatu Kajian Filosofis dan Sosiologis), Penerbit Toko Gunung Agung, Jakarta, 2002

Peter Mahmud Marzuki, Pengantar Ilmu Hukum, Kencana, Jakarta, 2008

Dosminikus Rato, Filasafat Hukum Mencari dan Memahami Hukum, PT Presindo, Yogyakarta, 2010

Riduan Syahrani, Rangkuman Intisari Ilmu Hukum, Citra Aditya, Bandung, 1999

Shidarta, B. Arief, Hukum dan Logika, Bandung;alumni, 2006

Solikin, 2002, Uang: Pengertian, Penciptaan, dan Peranannya dalam Perekonomian, Jakarta: PPSK BI

Kamus Besar Bahasa Indonesia (KBBI) http://www.dkn.go.id/site/index.php/ruang-opini/126-jumlah-pulau-di-Indonesia, https://databoks.katadata.co.id/datapublish/2018/10/16/berapa-jumlah-pulau-diindonesia. 